\title{
Do-It-Yourself Urban Design: The Social Practice of Informal "Improvement" Through Unauthorized Alteration
}

\author{
Gordon C. C. Douglas* \\ The University of Chicago
}

\begin{abstract}
There are numerous ways in which people make illegal or unauthorized alterations to urban space. This study identifies and analyzes one that has been largely ignored in social science: explicitly functional and civic-minded informal contributions that I call "do-it-yourself urban design." The research, which began as an investigation into more "traditional" nonpermissable alterations, uncovered these casesfrom homemade bike lanes and street signs to guerrilla gardens and development proposals - that are gaining visibility in many cities, yet are poorly accounted for by existing perspectives in the literature. This article examines the existing theories and evidence from interviews and other fieldwork in 14 cities in order to develop the new analytical category of DIY urban design. I present findings on the creators of these interventions, on their motivations to "improve" the built environment where they perceive government and other development actors to be failing, and on the concentration of their efforts in gentrifying areas. This introduces the possibility of conflict and complicates their impact. I argue that DIY urban design has wide-ranging implications for both local communities and broader urban policy.
\end{abstract}

\section{INTRODUCTION}

In 2010, when the City of Pittsburgh altered the traffic pattern at a hillside intersection in Lawrenceville, an area resident noticed that the change was confusing to some motorists and resulting in fender-benders. Seeing a need for better signage, he put his skills as an artist and illustrator to use, mocking up a design on his computer, using official fonts he had "picked up here and there," printing the design on a home vinyl plotter, and attaching it to an aluminum backing ("based on, you know, municipal criteria and things," he explained to me). The result, a shiny red and white sign reading "Cross Traffic Does Not Stop," was fixed to a pole below the stop sign at the intersection. Two years later it still stands as a valuable addition-as its creator observed, "there's a lot less plastic and glass in the street" - with the only indication of its origins the small lettering at the bottom that read "DIYDPW": the Do-it-Yourself Department of Public Works.

This sort of personal improvement to public space is not unique. In Los Angeles, one might find a group of friends painting a new bike lane along a road under cover of night;

\footnotetext{
*Correspondence should be addressed to Gordon Douglas, Dept. of Sociology, University of Chicago, 1126
} E. 59th St. Chicago, IL 60637; gdouglas@uchicago.edu. 
in New York, a woman designing innovative public seating and attaching it to existing infrastructure to make sitting and eating lunch on the street easier; in New Orleans, neighborhood residents writing their personal redevelopment ideas directly on abandoned structures and vacant lots; in Toronto, a man converting magazine racks and corporate advertisements into miniature herb gardens. What is happening? What motivates some citizens effectively to do urban planning and design work themselves?

Together, these actions begin to define a group of practices that I call do-it-yourself (DIY) urban design — small-scale and creative, unauthorized yet intentionally functional and civic-minded "contributions" or "improvements" to urban spaces in forms inspired by official infrastructure. I further divide the activities into three subcategories: guerrilla greening-planting or functionally converting unused land, infrastructure, or facades; spontaneous streetscaping-painting traffic markings or installing design elements such as signage, ramps, and seating on streets or structures; and aspirational urbanismpromotional signs, public notices, or other informational installations by which community members express their own policy and development ideas or alternatives. Though ancient in origin, in contrast to the widespread formalization and professionalization of urban planning and design practice in Europe and North America over the last two centuries (Levy 2011; Sutcliffe 1981), the trend of DIY urbanism may indicate something of a shift, or indeed a revival. Their many historical precedents notwithstanding, contemporary DIY urban design actions seem to find new beginnings in the 1960s and 1970s, around the dawn of the so-called neoliberal era, coming into their own (certainly rising in visibility) in just the last few decades ${ }^{1}$-in the company of conditions to which they respond and, as I argue, may also contribute.

Of course, all manner of unauthorized spatial interventions can be seen in the city, from juvenile bathroom graffiti to organized political demonstrations, and the literature has offered interpretations and generated theory based on many of these now-classic examples. Depending on the particular subject and approach of the research, some urban space interventions are claimed to constitute radical strategies of political expression, even theoretically potent "resistance"; others are described as acts of artistic or personal self-expression; still others are understood as little more than vandalism or "pointless" juvenile acting out. However, although I began my research informed by these interpretations, I have found that none of them provide a satisfactory lens for interpreting the work of the particular group of interventionists on whom I ultimately came to focus-those who, when confronted with something in their communities in need of fixing, improving, or enlivening, choose to do it themselves without asking permission. Civic-minded and intended toward the functional improvement of lived urban spaces through skillful, playful, and localized actions, these increasingly visible yet often unattributed practices complicate common assumptions and have received little attention from social scientists or urban policy and planning professionals.

This article examines the existing theories, describes many of the examples that challenge them, and develops a new analytical category that better accounts for the real world phenomena. I begin with a review of the aforementioned literature on urban space interventions in general: unauthorized, place-based direct actions that challenge the usual or regulated uses of particular urban spaces. Bringing in my findings from 2 years of fieldwork and supporting research, I draw out the new category of DIY urban design, defining it as distinct from existing assumptions. I then present additional findings about DIY urban design actions, the people who create them, and their connection to the structural 
conditions of the contemporary city. I uncover typical characteristics of "do-it-yourselfers" and their interventions that complicate the role and potential value of these efforts, including the possibility that one person's improvement may be another's nuisance and can have wide-ranging implications.

\section{RESEARCH DESIGN}

This study had two main parts or phases. In the first, I interviewed 18 individuals in New York, Los Angeles, and London on a wide variety of unauthorized urban intervention practices broadly defined, from politically motivated squatting and anarchistic occupations of public space to classic graffiti and street art, concluding in early 2010. As my interviews progressed, it became clear that some of the practices I was uncovering did not fit with existing interpretations in the literature. I thus began to seek out these liminal activities in particular in the second phase of research, in which I interviewed an additional 49 individuals specifically engaged in "DIY urban design" activities. In addition to interviews, the research included site visits with photo-ethnography, background research on participants and contexts, and in many cases participant observation during the creation and installation of DIY urban design contributions. This fieldwork was conducted in New York, L.A., and six secondary cities in the United States and Canada: Chicago, New Orleans, Phoenix, Pittsburgh, Toronto, and Vancouver. Additional information (including interviews) was collected without site-visits for individuals and their work in Baltimore, Dallas, Raleigh, Seattle, and the San Francisco Bay Area. ${ }^{2}$ A total of 57 do-it-yourselfers were interviewed, representing 55 different DIY urban design projects. In order to more fully explain particularly vivid examples and avoid overwhelming the reader with dozens of quick mentions, I limit here the number of detailed examples given and people from whom I quote directly.

The three initial cities, New York, L.A., and London, were chosen as major hubs of cultural innovation, known in particular to be visible centers of street art, guerrilla gardening, and the other types of urban intervention of interest to the research at its outset and, thus, where the largest populations of potential participants were likely to be found. As the phenomena of DIY urban design began to stand out and demand attention as a specific object of study, these cities remained clearly relevant field sites. Research then revealed Toronto as another major hub, and fieldwork was conducted there in June 2011. Further data collection remained centered in New York and L.A., with additional cases selected in the other cities with various historical, demographic, and urban policy conditions, and which media coverage and ongoing research suggested were known to contain valuable cases for understanding the phenomena.

Individual case selection was based on a logic of sequential replication (Yin 2002: 47), following a multiple-case-style "sequential interviewing" method (Small 2009). Each interview (and accompanying observations, etc.) is understood as one in a sequence of cases where questions are applied repeatedly and analyzed sequentially to support or challenge initial propositions, which are simultaneously revised to fit what is learned. A "snowball" referral method and ongoing investigation yielded additional potential participants. All 49 individuals who fit the criteria and allowed for constructive "literal" or "theoretical" replication (in terms of type of intervention, location, and other characteristics, as well as unique cases) were asked to participate, up to a point of saturation (no substantively new 
information gained from successive interviews within study parameters). All requests for interviews were granted.

\section{BACKGROUND AND LITERATURE REVIEW}

The study began as a broad investigation into the meaning behind a wide variety of unauthorized, place-based alterations and occupations of urban spaces. At this broadest level, there were many phenomena of interest, known by many names: graffiti, street art, happenings, situations, big games, pervasive games, art interventions, culture jamming, space hijacking, place hacking, Park(ing) Day, Critical Mass, Reclaim the Streets, protestivals, artivism, craftivism, anarchitecture, yarn bombing, guerrilla knitting, guerrilla gardening, guerrilla theater ... the list goes on. The motivations behind these practices are diverse, as are the scales of their intended (and actual) impacts. Yet all can be described as practices in which individuals or informal groups challenge expected, regulated uses of particular spaces through unauthorized direct action. I refer to them collectively here as forms of "urban space intervention," are few widely accepted terms that encompass them all. ${ }^{4}$

While scholarly research on urban space interventions is limited, there is a substantial body of popular discourse on the various individual phenomena. This includes: histories and surveys from respected art and design publishers (especially of street art, e.g., Chalfant and Prigoff 1987; Ganz 2004; Manco 2004; but also of interventionist art more generally, some of which do have critical academic authors, such as Lacy 1995; Seno et al. 2010); radical or independent press accounts of particular interventionist actions (e.g., Bloom and Bromberg 2004; Wilson and Weinberg 1999); "manifestos" and other publications by interventionists themselves (e.g., Fairey 1990; Moore and Prain 2009; Reynolds 2004); and the copious features, photos, interviews, and criticism to be found in both specialty and general interest magazines, newspapers, zines, websites, and blogs.

As for academic social science, there are relatively few focused studies of urban intervention practices, let alone relevant analyses of any collected meaning. Among what has been written, however, three main perspectives or categories of interpretation can be identified, dependent largely on the particular subjects in question and the theoretical or disciplinary background of the scholars. The first perspective, with its grounding in traditional urban sociology and criminology, considers a variety of practices as essentially just vandalism or trespassing, and frequently seems to imply that the acts have little deeper significance beyond serving as an indicator of crime and disorder. The bulk of the criminological and "broken windows" literature falls into this category, viewing illegal alteration as delinquency or simply a sign that "nobody cares" (e.g., Keizer et al. 2008; Sampson and Raudenbush 1999; Wilson and Kelling 1982). The case of Pittsburgh's "DIY Department of Public Works" and others described at the outset clearly complicate this perspective, as just the opposite of situations in which nobody cares.

The second category of accounts is similar but more sympathetic, granting unique research value to some forms of unauthorized intervention as instances of concept art, personal expression and communication, or popular subculture (e.g., Bartholome and Snyder 2004; Kidder 2012; Kwon 2002; Snyder 2009). These approaches analyze the activities for artistic, textual, or sociopsychological meaning, ${ }^{5}$ but as a result also consider 
their creators on these planes, making little accommodation for the intended physical or functional impact of the intervention itself and assuming personal motivations that rarely include wider political, economic, and geographical factors. They would fail to appreciate, for example, the reason behind community-regarding and often selfless and anonymous improvements like the intersection warning sign in Pittsburgh, or the socioeconomic context of an unauthorized bike lane, garden, or development proposal.

A final category-perhaps the most sympathetic to its subject—frames activities ranging from street art to street festivals in terms similar to radical activism and protest, sometimes with explicitly stated wider political goals and often inherent (if entirely theoretical) critical transformative potential. This perspective may be the most commonly advanced in the literature, at least about any of the forms of urban intervention more elaborate than graffiti. It has been relatively clearly and objectively articulated by cultural criminologist Jeff Ferrell (e.g., 1995, 2001), who is also one of few scholars to connect many similar urban intervention practices as a group. He proposes that urban space has become increasingly regulated, policed, and commodified over the past several decades, and views graffiti, busking, bicycle activism, and the other activities that he collects as "urban anarchy" as increasingly and consciously reactive to this. Others present the alternative uses practiced by "outlaw" bike messengers or skateboarders as symbolic challenges to spatial regulation (e.g., Kidder 2011; Vivoni 2009). Many observers in this camp go so far as to suggest the actions qualify as instances of outright "resistance" to authority, capitalism, or mainstream culture in the critical or neo-Marxian tradition (e.g., Lambert-Beatty 2010; Pickerill and Chatterton 2006; St. John 2004).

This perspective is harder to dismiss directly as inapplicable to DIY urban design activities, and I initially approached my own research on urban intervention from such a standpoint. Site-specific direct actions, such as the "Reclaim the Streets" demonstrations of the $1990 \mathrm{~s}$ - where streets were illegally closed to traffic by raucous impromptu carnivals while jackhammers helped replace asphalt with saplings-seemed empirical actualizations of the sort of popular resistance implied by Henri Lefebvre (e.g., 2008, 2009) and other theorists arguing for the transformative potential of "critical consciousness" in everyday urban space.

Indeed, even if essentialized somewhat for comparison, none of the three existing perspectives I have described are baseless "straw men," nor are they mutually exclusive. Again, to some degree the difference between the three perspectives has as much to do with case selection as interpretation. There seems little doubt, for instance, that some graffiti $i$ associated with neglect and "disorder" (Keizer et al. 2008), not to mention crime and violence (Phillips 1999). And certainly a great deal of street art is as much about personal motivations like bucking the gallery scene or going "all city" with one's work as it is about some nobler reclaiming or improving of urban space. Snyder (2009) found in his ethnography of the New York graffiti scene that the primary motivation for tagging among the artists he studied was essentially achieving some minor degree of subcultural fame. Finally, from graffiti writers to participants in alter-globalization "protestivals" and "occupations," there $i$ s evidence that many site-specific artists and activists do see their interventions in radical, revolutionary political terms well beyond the sites in question. In some instances, like Reclaim the Streets or the place-remaking of the Occupy movement, there is a case to be made for that.

However, my initial study across three cities began to turn up many cases that simply did not fit neatly with the existing perspectives. I interviewed a range of people, from 
groundbreaking 1980s graffiti artists in New York to the principal organizer of Reclaim the Streets in London, but I also found guerrilla gardeners, unauthorized streetscapers, and fake sign makers whose work seemed different. I began to see that an emphasis on critical resistance was missing out on the subtler and often more local and individual motivations that many have for altering the built environment like this, and their more limited intended impacts directed largely at simple, functional improvement. In dropping my early assumptions, I found that many such practices are better described (and thus distinguished) by a fourth logic-the logic of DIY urban design.

Defining and analyzing the concept is the purpose of the rest of this article. By way of placing it in the literature, several items are worth discussion. In the popular realm, websites, magazines, and the occasional book have begun to touch on these themes (e.g., Burnham 2012; Douglas 2011a; Hou 2010; Klanten et al. 2010; Lydon 2011; Partizaning 2012; Veloz 2011). In 2012, the U.S. pavilion at the Venice International Architecture Biennale even celebrated similar phenomena with the exhibition "Spontaneous Interventions: Design Actions for the Common Good" (see Ho and Douglas 2012).

In social science, a brief and only just emerging interest in these themes can be identified. A study by Visconti et al. (2010) conceives of some forms of urban intervention this way, if not quite explicitly. They argue that forms of "place marking" range from "pure resistance and contestation" to "public place beautification" and note the diversity of forms of alterations. Though ultimately focused "solely on those street marking practices imbued with multiple ideologies of reclamation of public place" (p. 514), among six types of marking that the authors distinguish is "urban design"- "an aesthetic practice applied in favor of the beautification of public architecture and urban style," where the ideologies behind the actions are about the right to alter that space and the goal is "enchanting" the city for city dwellers. More recently, a handful of researchers from different disciplines have also begun to share work and develop a discourse on similar themes (e.g., Douglas 2011b; Finn forthcoming; Iveson 2012, 2013), though nomenclature and definitions are still varied and debated. ${ }^{6}$

My study turns a sociological lens on the creators of the unauthorized improvements that I call DIY urban design, exploring their backgrounds, motivations, and selfperceptions. It also works to interpret these phenomena more explicitly in the context of the sociostructural conditions of the contemporary city. Not unlike forms of collective action (Tilly 1978), I suggest that urban interventions are contingent upon their social and historical contexts. Though cities have always been organic projects, as discussed, after more than two centuries of increased management and professionalization of urban planning and both normative and legal tightening of control over the use of urban space (Fishman 2000; Keller 2009; Levy 2011; Sutcliffe 1981), the reemergence of unauthorized, DIY approaches to the built environment since the 1960s might be described as a phenomenon of the so-called neoliberal era (see also Douglas 2012). Seemingly coincidental with this period of economic restructuring and deregulatory policy, DIY urban design can be seen as both a reaction to and product of the structures and processes that define the contemporary city-trends such as state disinvestment, commodification, gentrification, and a general intensification of uneven development (Brenner et al. 2010, Fairbanks and Lloyd 2011; Harvey 2006; Smith 2008 [1984]). Guerrilla gardening, hypothetical development ideas, and unauthorized street improvements are direct responses to the perceived neglect of some spaces, while advertising removal, aspirational proposals, and propedestrian interventions react to the hyper-commodification or insensitivity 
of others. In the next section I present examples from my research to further define and distinguish the practice, the characteristics and motivations of its practitioners, and the contexts in which they act.

\section{FINDINGS}

\section{WHAT IS DIY URBAN DESIGN AND WHAT IS IT NOT?}

DIY urban design refers to creative practices aimed at "improving" the local built environment without permission in ways analogous to formal efforts. While more active, functional, and goal-oriented than what might plausibly be dismissed as "just art" or "just crime," these actions are far more subtle, limited, and place-based in focus than the tactics of a broader political activism or resistance. Yes, some do constitute vandalism, many have artistic and personal elements, and few could claim to be wholly apolitical. Yet they largely lack elements of destruction, self-promotion, or political communication and are defined far more centrally by their thoughtful, civic-minded design and functional implementation.

Consider the case of the Highland Park Book Booth, a public book depository created out of a long-defunct payphone that has (apparently quite successfully) been fostering literary exchange in its Los Angeles neighborhood since 2010 (see Figure 1). "It had the phone pulled out of it. It'd been like that for as long as we can remember. So we just kept thinking of an idea to use it," its creator, Amy, a book designer and gallery owner, told me. "And so, after like two years of trying on all these ideas, and walking by this thing, I decided 'OK, book giveaway!' The Book Booth is a positive response to urban disorder and neglect, not a symptom of it. Artistic merit notwithstanding, the design is simple and functional (the major additions, other than books, being a shelf, a small sign, and a bit of yarn decoration that someone added later); while Amy is happy to acknowledge and discuss creating it, it has no signature on it and intends to convey no greater message than the value of books and a wish to turn a neglected bit of city infrastructure into something useful, appealing, and unexpected.

Much the same can be said of the illegal bike lanes created by Toronto's clandestine "Urban Repair Squad," or a faux-civic sign (in English, Korean, and Spanish, with all the requisite names and contact information) declaring a new city park on a prominent piece of property actually slated for condo development on L.A.'s Wilshire Boulevard. And the same can also be said for the myriad unauthorized benches, planters, plants, signs, and other streetscaping installed at needy or neglected locations by community members in many cities. These are neither situations where nobody cares, nor instances of juvenile acting out or (primarily) artistic expression. Attempts to fit them into such categorizations miss out on their potentially deeper sociological and geographical significance, especially in terms of motivation and intended impact. And so too is it a stretch to equate such actions with organized protest or resistance.

Some of the interviewees do see their projects as campaigns of sorts (i.e., a series of similar interventions in multiple locations, even multiple cities), but most create things only sporadically, focused on particular spaces or types of places. Some connect the actions with loftier political beliefs (environmentalism, for instance, or opinions on urban policy issues such as cycling infrastructure) around which they are actively mobilized, but 


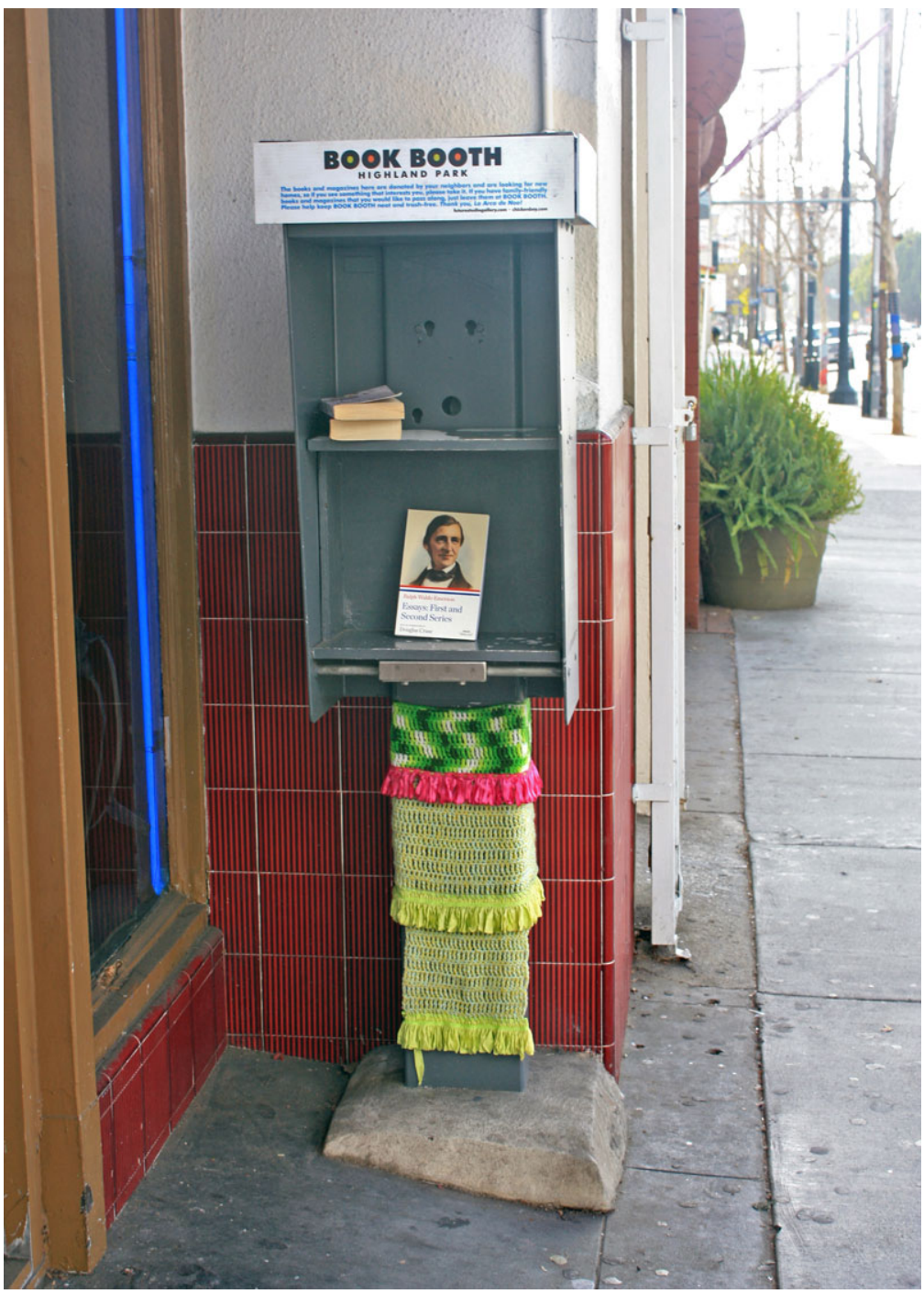

FIG. 1. The Highland Park Book Booth, a public free book exchange created out of an abandoned payphone by Amy Inoue and Stu Rapeport, Highland Park, Los Angeles, 2010. Photo by the author.

many others do not or dismiss the idea that their interventions have a political impact. "I have too much respect for activists and what they do to call myself one," one New York interventionist told me. Most also express little interest in promoting themselves or their work; some enjoy seeing their creation noticed, but others argue that the best contributions are those that are entirely assumed to be legit, thus lasting longer and serving a functional purpose. As opposed to organized political efforts, these actions more prominently represent a simple willingness (and perceived right) to reshape the built environment on one's own terms. 
Furthermore, if it is true that many of the individuals involved have little love for "the system," their projects are no more aimed at overthrowing it than they are at vandalism, self-expression, or self-promotion. While I have certainly found some difference on the measure, many of my interviewees actually expressed a clear disinterest in stirring things up and were resistant to the idea of themselves as radicals. "There's no reason this couldn't be done legally and with city authorization," explained one member of L.A.'s so-called "Department of DIY," responsible for illicitly painting bike lanes, softening square curbs, and other such improvements. A majority of the do-it-yourselfers I spoke with demonstrated considerable familiarity with urban policy and planning processes in their communities, and some DIY actions even work toward specific city plans. Martin, a photographer and representative of Toronto's Urban Repair Squad, describes one of their interventions, some of the first bicycle shared-lane arrows in the city:

Again it was supposed to be installed [i.e., was called for in the city bicycle plan], it was a very easy job, it was 800 meters worth. ... And [the Urban Repair Squad] did it I think in two night sessions on both the north and south sides of the street in like three hours? It cost 80 dollars instead of 25,000 dollars or whatever it's supposed to cost, including the design which takes up a lot of money. And that stayed up for two years, nobody ever caught on. Eventually - it's really ironic - eventually two years later they actually got around to painting it. So you now have like the city stencils and the Urban Repair Squad stencils side by side.

As discussed further in the following section, do-it-yourselfers see themselves as aiding the city, their fellow community members, and in some cases even landholders and developers. Their actions may be embedded in a politics of localism and a frustration with the formal process, but they are subtle in impact and statement, first and foremost about simply making a positive, functional contribution.

This does not mean that DIY urban design (or any one of the other categories) is necessarily exclusive of the others, just that the other categories miss out on its more central features. Consider a case of DIY urban design that has at once some elements of vandalism, artistic expression, and political protest: Jordan Seiler, a formally trained artist in New York City, removes corporate advertisements from streets, payphones, and bus stops and replaces them with artwork or blank canvases. Well-versed in civic codes and ordinances as well as critical geographic theory, his actions are anything but random, and he devotes most of his efforts in New York and other cities to removing illegal advertising (such as promotional "wildposting" on walls, poles, and construction sites) that the city should be preventing. As Jordan says:

It's really nice to see outdoor advertising kind of fold under pressure, but at the same time, I would say the project gets clouded in the resistance to advertising, but it's much more about [...] playing with the city, and understanding that if you have an opinion about how space is maybe improperly being used, you really have the right and the ability to go out and make some sort of alteration to that situation. [...] I mean a hundred and fifty people going out and whacking house on illegal advertising in the city should be a positive!

One might assert that Jordan's "Street Advertising Takeover" does "resist" the prevalence of outdoor advertising and the commodification of public space. Guerrilla bike 
lanes, street furniture, or aspirational park "proposals" also, in a sense, "resist" the likes of car-centric urban planning, uneven investment, and other perceived problems. If these are the views of the do-it-yourselfers (and they largely are), it seems fair to argue that such actions are perhaps on par with the sort of targeted "everyday resistance" described by Scott (1985). But a focus on more theoretical, radical, transformative implications in much of the literature misses the driving motivation toward simply improving the city, ostensibly for everyone, where the city or other powers that be should but cannot or will not do so. Ted, a member of the Brooklyn-based "tactical urbanist" collective DoTank (noted, among other things, for "chair bombing" the streets of Brooklyn with Adirondack chairs and other furniture built from old shipping pallets), summarizes the logic of DIY urban design well:

It's guerrilla. It's sort of unauthorized, and it's somewhat illegal, and it gives us anonymity in there because of that, but then it's not politically charged, and it's not defacing. Right? It's sincerely meant for - it's functional. From the standpoint of maybe helping you, or maybe it even helps everyone, or more than just yourself.

Yet DIY urban design practices are not simply noteworthy for the novelty of their distinction from previous assumptions about the unauthorized alteration of urban space. Beyond the distinction from other forms of unauthorized urban intervention, what else do these practices actually look like? Physical differences across projects and across types of projects indicate the breadth of ways that people create unauthorized improvement. Specific examples from my research, of what I call guerrilla greening, include tending neglected road medians or vacant lots to create flourishing gardens, converting parking spaces into impromptu parks, or, as we have seen, replacing corporate advertisements with anonymous art and repurposing phone booths into book exchanges. Spontaneous streetscaping includes painting bike lanes and crosswalks without city approval, creating historical markers commemorating unheralded events, amending road signs with improvements so good they go unnoticed, and building and placing public street furniture in neighborhoods that lack it. Examples of aspirational urbanism include public wishlists on vacant walls enabling community planning input, official-looking "coming soon" signs for hoped-for parks or subway stations, and faux regulatory signage "enacting" a policy change such as allowing bicycles on subway trains. In addition to these differences of form, DIY urban design actions each also have their own inspirations, contexts, and intentions. I now discuss the "who," "why," and "where" questions of DIY urban design practices and their creators, before addressing the final question of "to what ends?"

\section{WHO, WHY, AND WHERE?}

In terms of basic demographics, while again mine is not a random sample, some common characteristics of the do-it-yourself urban designers I studied are worth noting. All of my respondents are in their late $20 \mathrm{~s}$ through late $50 \mathrm{~s}$ (with most in their early $30 \mathrm{~s}$ ), they are primarily white (though Asians make up a sizeable minority, followed by a smaller number of blacks and Latinos), and I spoke to about twice as many men as women. They come predominantly from middle-class backgrounds, and most have at least some postsecondary education, ranging from undergraduate and art school coursework to graduate and professional degrees; a handful of exceptions include community members 
involved in several projects in underprivileged parts of Los Angeles, New Orleans, and Oakland. Most do-it-yourselfers I met have stable day-jobs of a wide variety, from things like professional art practice, writing, and small business ownership to careers in formal design and urban planning-sometimes with direct relevance to the DIY projects they create "after work." Put bluntly, though there are exceptions, the vast majority of the individuals I interviewed qualify as members of the so-called "creative class" (Florida 2002). On more subjective measures of appearance, many of them also match a particular subset thereof: the young, middle-class urban neighborhood newcomers looking for (and making) "neo-bohemia" who interest many in urban studies (Lloyd 2006; Zukin 2010).

Suffice it to say that even in these terms DIY urban designers differ significantly from common assumptions about people who make illegal alterations to urban space in other ways (street art, vandalism, squatting, protest). And indeed, very few of them have done "a lot" of this or other quasi-illegal things at all. Many are interested in graffiti and street art, for instance, but only a few I talked with had any experience with it. When a group of cyclists planned to place a series of "pass with care"/"pase con cuidado" road safety signs up around Los Angeles in 2010, they enlisted the help of veteran street artists to make the wheat paste. On the other hand, those do-it-yourselfers with professional design training put their formal skills to use in their projects (sign-makers making signs, industrial designers creating chairs and benches, etc.). The handful with direct familiarity with formal planning processes through schooling, careers, or engagement in local politics are clearly informed by this knowledge. And where they lack a professional background, DIY urban designers often seek information from official sources, such as what paints the Department of Transportation uses for curbs and bike lanes, how wide they should be, and where they are called for in planning documents.

With regard to motivations and inspirations, all of my interviewees could clearly explain why they do what they do in an immediate sense. Motivations always featured seeing a specific spatial "problem" affecting them and/or their communities and a feeling that they could help "fix" it themselves. The particular DIY urban design responses are often inspired by their own skills, interests, and backgrounds, or in many cases by hearing (usually via the internet) about something similar that others have created; frequently both. For instance, the bike lane painters I spoke to in Los Angeles invariably say their actions are a response to the city's lack of such infrastructure, and also that they were directly inspired by Toronto's Urban Repair Squad, who began doing similar things a few years earlier. A visible need and inspired response were also the case with a DIY effort to address the lack of street seating in South L.A. As in many urban areas, seating and shelter at bus stops in L.A. are largely provided by the advertising companies that use these structures as displays, so where there is no advertising, there may be no place to sit. In this case, a group of area residents and parishioners of St. Michael's Catholic Church, working with architect Steve Rasmussen Cancian, worked together to create sidewalk furniture themselves in the style of the "community living rooms" Cancian has helped design in Oakland and other parts of Los Angeles (see Figure 2).

Beyond immediate fixes, however, many do-it-yourselfers I spoke to were less confident when asked about long-term objectives or wider impacts. As suggested in examples mentioned above, the broader intended outcomes of these actions vary widely, from the simple and place-specific (improve this street, repurpose that phone booth, brighten up those vacant lots) to more ambiguously inspiring others to see and think about the urban landscape differently and perhaps take similar actions themselves. But while they differ 


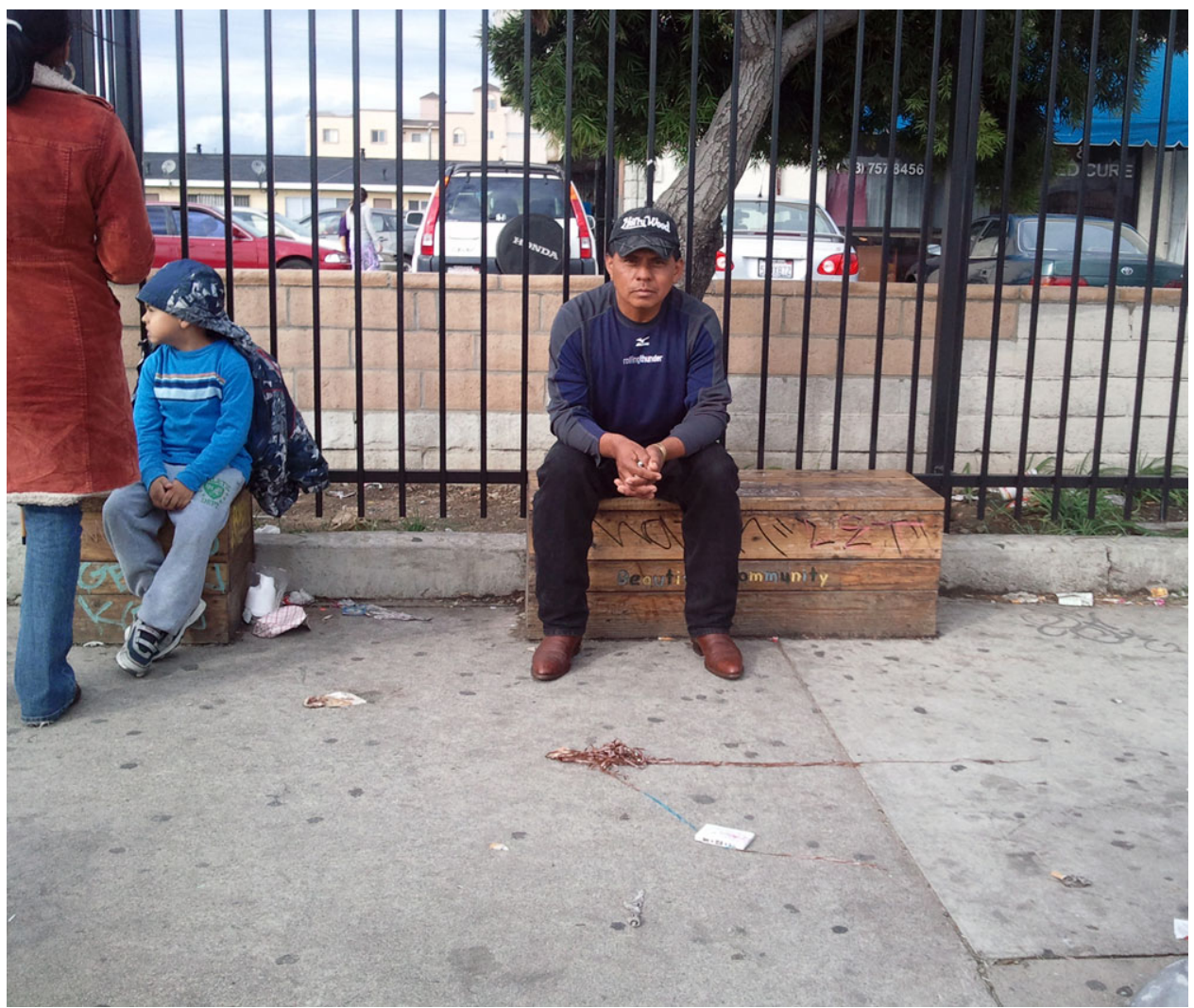

FIG. 2. A man waiting at a bus stop sits at one of several benches and other sidewalk furniture installations placed around South Los Angeles by community members and parishioners of St. Michael's Parish Church, in collaboration with Steve Rasmussen Cancian, 2010. Photo by the author.

in the scope of the impacts they imagine for their projects, without fail they express confidence that what they are doing is good, needed, filling a void where the city (or property owner, or whoever) has dropped the ball.

If stepping up where the city has slouched is a motivation, would they prefer the city to do it? My respondents are divided on this, and seem fairly conflicted internally as well. Many of the people responsible for what I have described as "aspirational" projects are more or less by definition calling for something to be done formally, even in cases where the project itself is satirical, like the park announcement in L.A. mentioned above. Candy Chang's "I wish this was..." sticker campaign in New Orleans and elsewhere, which invites community members to propose their redevelopment ideas directly on vacant properties, is another example. Many people painting illicit bike lanes or fixing signs told me they would love for the city to do such things as well. However, as another guerrilla lanestriper affiliated with the L.A. Department of DIY put it, "we have the paint, we have the stencil, why wait for the city to do it?" There is widespread frustration with the bureaucracy of planning processes and a common feeling that the city does not or would not do it right anyway, so it is better when "the people" do it. An example is Richard Ankrom's 
2001 "fix" of a confusing Downtown L.A. freeway sign: even after his additions were acknowledged by the California Department of Transportation 2 years later, the sign was left untouched until routine updates in 2009 facilitated its replacement-and then with all of Richard's changes intact.

Going further, many of those I spoke with promoted the idea that the unauthorized aspect of the action is important in itself. Joe Linton, a resident of L.A.'s "Eco-Village" community-who with his neighbors painted a mural in their intersection, striped their own crosswalks, and placed seating and trees in a concrete bulb-out, all intended to calm traffic on the street-puts it this way: "It appeals to me a lot to get a bunch of friends together and just do something, and do it in an open, creative way. Don't wait for anybody to give you permission." Some would like to see a more "open" city in general, in which everyone is inspired to step up and make needed improvements. And for others of course, it is also more fun. As with Joe, Jordan, and the various folks with professional day-jobs who have described the thrill of almost getting arrested while painting bike lanes, or the freedom they felt throwing a "seed bomb" over a chain link fence, there is a joyful element of release, excitement, and creative accomplishment.

Another of my interviewees summed up a lot of the motivations and inspirations that I heard in my interviews, when she explained how she and her partner (both professional industrial designers) started making DIY improvements like the SignChair, a folding seat that attaches to existing street signs:

We were just kind of looking into ways that we could make the street more comfortable. The whole point of it is to make the place better to be in. It would be great if the city did it, but I think for us to expect and wait and hope for the city to do something like this is unrealistic. And it's fun for us to try to participate in making and shaping our own neighborhood!

Across all of these motivations, justifications, and goals, the decision to make DIY alterations like these also implies a strong sense of self-entitlement. It involves a value judgment of some neglect or deficiency or opportunity in the space that the do-it-yourselfer hopes to address, and a willingness to make changes to the community based in large part on one's own preferences. At a minimum, "we're not hurting anybody" is a pretty common sentiment among everyone I spoke with, yet from Jordan's advertising removal to the installation of signage or street furniture, one person's improvement may well be another's vandalism. (At what might be viewed as an especially antisocial extreme, what one of my respondents called his "DIY urban planning" effort involved removing a bus stop entirely from the street outside his Seattle home, after the city ignored his pleas to place a trash can there.) Jordan recognizes the difference in opinion about his efforts to remove illegal advertising from New York City streets: "Bloomberg should be like 'Awesome! Thank God I didn't have to send the anti-vandal squad after these dudes, you guys took it upon yourselves!' Instead nine people are arrested." Deborah, the woman behind a mass planting of flower seeds in Brooklyn, was surprised that her effort, conceived as a "gift" to her adopted community, was met with a critical tone in the press and among some neighbors.

These examples - and especially the last one-bring to light a final, fundamental component of DIY urban design contributions: the particular contexts in which they occur. I have documented projects in all types of places, from leafy streets in suburban 
Los Angeles County, to isolated vacant lots in New Orleans' Central City, to busy avenues in Midtown Manhattan. Some are effectively "generic" or citywide, such as Jordan's advertising removal or the Urban Repair Squad's posting of green "bikes allowed" stickers in every Toronto subway station. Many others are of course undertaken in quite particular locations-for instance, the traffic sign in Pittsburgh with which this article began, or the public park "announced" atop a site where condos were planned. On balance, however, the most common factor in a project's location seems simply to be relative proximity to the home or workplace of its creator(s). These, in turn, are most frequently in or near the sort of rapidly changing urban neighborhoods where we might expect the young, creative types most often responsible to be living, if not to have grown up. The Book Booth described earlier, for instance, is just down the block from the gallery that Amy and her partner own, in the currently trendy (if historically artsy) L.A. neighborhood of Highland Park. Ted and his colleagues at DoTank have installed their hand-made chairs and other projects in hip Brooklyn neighborhoods like Williamsburg and Clinton Hill, near where they live. Richard Reynolds, a London advertising professional noted for jump-starting the "guerrilla gardening" movement in 2004, began outside his own apartment building in up-and-coming Elephant and Castle. And Brooklyn's Bedford-Stuyvesant neighborhood, where Deborah organized her unexpectedly controversial "seed bombing" effort, is a current poster-child for first-wave gentrification in New York City.

In other words, DIY urban design actions appear to be more common in newly hip and "gentrifying" neighborhoods than in the impoverished inner-city "ghettos" or derelict industrial districts one might think of as the more visible "victims" of neoliberal policy and state disinvestment, where DIY actions should ostensibly be most "needed." Among the exceptions, a group of connected projects in California does offer an interesting counterpoint: the "community living rooms" that architect Steve Cancian has helped organize in Oakland and L.A. are largely initiated, designed, and built by long-time residents acting in their own neighborhood, and with the explicit goal in most cases of improving an under-privileged neighborhood while discouraging gentrification. By building community seating and gathering places on the streets (also including flowerboxes, murals, and in one case a basketball court and electric lighting), the idea is to create public spaces that are used by long-time residents, making their ownership of the area more present and visible. All in all, my interviewees are generally aware of the larger urban conditions of disinvestment, public inaction, and uneven development that their actions can be seen as reactions to. But in terms of specific locations-as well as the motivations and goals behind them-many DIY urban design contributions are relatively personal passions, with potentially unintended consequences.

\section{DISCUSSION}

These findings about the phenomena of DIY urban design suggest a number of further implications. From the perspective of academic research, the fact that people are taking it upon themselves to make these unauthorized contributions to the material environment suggests a number of lines of sociological inquiry, raising questions for the study of contentious politics and social movements, urban art, and crime and disorder, as well as urban planning, design, and development scholarship. It responds to sociology's 
persistent need, recently stated eloquently by Kidder (2011:142), to recognize that "Physical structures, just like social structures, are intertwined with human agency."

Perhaps most important, and the focus of the remaining pages, the interventions themselves also have daily and long-term practical implications for the communities in which they occur. From seemingly innocuous efforts at tossing "seed bombs" into vacant lots or planting flowers in unkempt tree wells to the installation of functional signage and streetscape infrastructure, DIY urban design actions do not occur in a vacuum. By definition, they tend to happen on someone else's property, whether private or public, potentially costing owners or taxpayers money, and impacting anyone in the surrounding area. How should local governments or property owners respond? Whose control, authority, or claims are challenged by the assertion of previously unclaimed rights or responsibilities such as these? Who benefits and who is harmed? Does this represent a cost to taxpayers and property owners, or a potential economic boon? Is it, on measure, a net benefit to the community and the city?

Measuring the impacts of individual DIY urban design actions is an important project for future research, yet certain possibilities warrant discussion here. In particular, the characteristics of many do-it-yourselfers I studied (often members of the "creative class"), their motivations (making creative, functional "improvements" where they see an unmet need), and the places they act (urban areas experiencing conditions of uneven investment and development, in which they are often not long-time residents) portend possibilities of overreaching, to say the least. Add to this the favorable attention that interventions often receive in trendy publications, and it is entirely possible, for instance, that these ostensibly counter-cultural acts of organic, positive, informal contribution may, just like official urban design improvements, ultimately help increase property values, and thus precipitate and even encourage the gentrification process. ${ }^{7}$ Concerns about gentrification and neighborhood change were certainly an explicit concern for those upset with Deborah's guerrilla gardening efforts in Brooklyn (see also Correal 2009), as they are for people building "community living rooms" in Oakland and L.A.

Even if one cannot clearly connect individual DIY improvements to changes in property values and median monthly rents or the displacement of particular groups, it is likely that they do more good than harm to a neighborhood's "appeal." The simple fact that any such activities are happening at all could potentially, as signs of social organization and trendy activity, increase the attractiveness of some urban neighborhoods. ${ }^{8}$ In other words, if neoliberal conditions such as uneven development make space for DIY urban design, it may also be the case that some DIY urban design enables or encourages the continuation of these very conditions. The creators of these interventions may not only be acting in the context of neoliberal processes, but may be inherently part of these processes through both their direct actions and their longer term impact.

Still, this need not lessen the positive potential inherent in the fact that people are making these sorts of contributions. It suggests the need to better understand them, to view them with a critical eye, and consider them as one would any other intervention in urban space (formal or informal) with the ability to do good or do harm. The trend of DIY urban design is inherently a fairly explicit challenge to basic normative assumptions about who controls, designs, pays for, and physically makes particular spaces or types of spaces. It also contains an implicit questioning of wider identities, politics, and economic processes, and seems to question their efficiency. We do not usually think of the urban 
built environment as something we can reshape at our whim; its uses and meanings are normatively-and often legally-defined and regulated, and essentially altered only by publicly accountable professionals. Yet for better or worse the subjects of this study treat the infrastructure and public spaces of the city as open to popular reinterpretation, especially where the powers-that-be appear to have slouched.

This study has suggested a new way of understanding unauthorized alteration of the built environment, a subject of research that scholars have heretofore viewed as either self-centered vandalism or self-expression or politicized tactics of radical protest and critical resistance. The concept of DIY urban design provides a more complete understanding of unauthorized urban space intervention. The study also reveals who the DIY urban designers are, why they choose to act informally, and in what contexts. This in turn has implications for our thinking about sociological issues such as individuals' relationships to the built environment, the meanings and motivations of unauthorized (in many cases illegal) practices, and formal and informal responses to symptoms of neoliberalization, such as uneven development and unequal investment in urban communities. While the act of unauthorized improvement may be a reaction to perceived neglect and disinvestment in an area and a symbol of organic creativity and social organization, we must remember that in many cities today development capital is quite happy to take advantage of any "sign of life" and run with it. Personal and cultural practices in urban space cannot be separated from political-economic processes and structural contexts. In these ways, the study also continues the project advocated by Fairbanks and Lloyd (2011:5), among others, for ethnographic analysis of "actually existing neoliberalism."

Finally, more research on DIY urban design practices and their creators is necessary to reveal the mechanisms behind these phenomena and their cultural, spatial, and socioeconomic relevance. The rise of DIY urban design may represent a shift in how people in the United States and other advanced economies relate to the physical and policy environment of the contemporary city: a willingness to make would-be improvements to a place without permission, taking their ideals for urban space into their own hands, in a sense doing professional urban designers' work for them. This shift implies changes to how we conceive of the boundaries between personal, public, and private property, of who is entitled to alter urban space, of the authority and responsibility of local government, of urban use value, and yes, of creative, critical, personal agency. To the degree that these actions are an indication of what some people actually want out of their urban surroundings, we could learn a great deal about how to design our urban spaces more responsively in the first place. We should seek to understand them better before (quite literally in some cases) simply brushing them off.

\section{Acknowledgments}

Much of this research has been presented in earlier forms at annual meetings of the American Sociological Association, the Association of American Geographers, and the Exploring the Creative Economy conference, all of which occasioned highly valuable feedback. I am grateful to the editors and anonymous reviewers at City $\mathcal{E}^{\circ}$ Community and many colleagues at the University of Chicago and beyond for their comments and suggestions in improving this article, and am especially indebted to Emily Art, Andrew Abbott, Kristen Schilt, and Mario Small for their support. 


\section{DO-IT-YOURSELF URBAN DESIGN}

\section{Notes}

${ }^{1}$ All practices of informal urban intervention have their historical antecedents, going back at least to ancient Rome in some cases, and some of them have been with us ever since. Yet many have been part of urban life in their contemporary forms for less than half a century (modern graffiti and street art being perhaps the bestknown example), even beginning within a short time of one another and growing in prominence and diversity together over the past few decades. The constituent phenomena of DIY urban design follow right in step: The general DIY trend as we know it emerged in the 1960s and 1970s (Leland 2004). Guerrilla gardening (as such) first appeared in 1973 in the company of squatting and other place-based protest against gentrification of New York's Lower East Side and has flourished ever since, with the term reinvigorated in 2004 and now visible in cities around the world. The installation of public seating or the repurposing of things like magazine racks or fire hydrants may date from other informal urban spatial experiments in the late 1960s and the rise of public interventionist art in the $1970 \mathrm{~s}$, and is connected by my subjects with the street art installations and "place hacking" of the last decade or so. While people have doubtless been altering official signs for as long as they have existed, the earliest example I have found of anyone pitching a fake aspirational improvement as a real forthcoming development is as recent as 2000. Most creators of DIY signage and street improvements I interviewed point to Toronto's Urban Repair Squad as the seminal example, beginning in 2006, or the freeway sign improved by Richard Ankrom in 2001. All of these practices have also become more "popular" of late in terms of books, magazine articles, websites, and exhibitions on the subject.

${ }^{2}$ Additional fieldwork connected to this research (including several interviews), was carried out in Mexico City and Tokyo, and interviews with select urban planning, design, and architecture professionals were also conducted in Los Angeles and New York. However, no analysis or interpretation of these data is included in the present findings.

${ }^{3}$ The word intervention here references its use in both the art and activism worlds, and an especially "activist" form of art in particular: initially the "art interventions" of the Dadaists and others (usually literally intervening in other pieces of art, audiences, and venues), but even more so its subsequent reinterpretation in so-called "relational aesthetics" (Bourriaud 2002 [1998]) and other site-specific practice as interjections into public space and everyday life (see Kwon 2002; Klanten et al. 2010; Thompson and Sholette 2004). The term is used widely among practitioners of many of the different phenomena listed, from street art to guerrilla theater, and exemplified in an exhibition on "the creative disruption of everyday life" at the Massachusetts Museum of Contemporary Art in 2004-2005 called "The Interventionists: Art in the Social Sphere" (see Thompson and Sholette 2004). The phrase urban intervention suggests actions directly impacting urban space itself without prejudging scope, temporality, or value, and makes allusions to the art and activism contexts above without being beholden to either. Many of my own interviewees have used-if not embraced-it as a general term.

${ }^{4}$ It is worth noting that all of these phenomena would also seem to qualify as instances of what Jeffrey Kidder (2011, 2012) has called the "affective appropriation of space," essentially the imbuing of urban space with personal cultural meaning through alternative uses. Yet in comparison to what I call "urban interventions," Kidder makes no requirement of illegality or transgression (see Kidder 2012) and has focused on temporary activities in urban space, not physical alterations (much less intended improvements) to it. Less transgressive actions, such as sanctioned community gardens and public art, or organized protests and demonstrations in urban space, are also worthy of attention, as is the simple act of putting pride into reimagining one's own property, but my study draws the line at actions undertaken illegally or without permission where it is normally required. More transient or ephemeral unauthorized practices, such as sidewalk sleeping and squatting, and some skateboarding and cycling, constitute a gray area but meet my definition as urban interventions where they work to challenge the expected uses or meanings of the spaces they transgress. Of course, as described in the remainder of this article, not all urban interventions (or all affective appropriations) are DIY urban design. See Kidder (2011, 2012) and Visconti et al. (2010) for insight on some similar boundary questions. 


\section{CITY \& COMMUNITY}

${ }^{5}$ For instance, another popular premise for the study of graffiti has been its analysis for sexual and cultural significance when scrawled on bathroom walls, as has been done by everyone from biologists (Farr and Gordon 1975; Kinsey et al. 1953) to English professors (Bartholome and Snyder 2004).

${ }^{6}$ Why "DIY"? These three letters have a great deal of meaning in Western subculture and counterculture, rooted in 19th and 20th century Arts and Crafts and "back to the land" movements, and emerging alongside hip hop and punk ideologies and aesthetics in the 1970s (Leland 2004). Of course, the term refers most simply to any creating, repairing, or modifying done by oneself rather than by professionals, but through these subcultures has come to represent an ethic of nonmainstream self-reliance in everything from home-brewing, self-publishing, and traditional craftsmanship to illegal parties and radical spatial protests like those mentioned earlier. The culture and term are lately experiencing a boom in popularity, especially in the hip, gentrifying urban neighborhoods that we associate with trendsetting and the creative class (see, e.g., Kimmelman 2010; Ryzick 2007; Stern 2010). The term DIY is also already connected with many urban intervention practices, especially graffiti (Ferrell 1995; Rahn 2002), but also guerrilla gardening, street performance, and squatting. When placed in front of the words for the quite formal practice of "urban design," the term suggests just the unique, unlikely combination of methods and motivations embodied in the act of altering the built environment in order to make functional, civic-minded improvements to it without permission.

${ }^{7}$ For example, two studies of the community gardening movement on New York's Lower East Side during the 1970s and 1980s (Schmelzkopf 1995; Von Hassell 2002) discuss the rise of vacant lot gardening led by local activists as part of the larger antigentrification struggle of the area's residents. They were attempting to preserve and improve vacant land by converting it into gardens. Yet this was only partly effective in its direct protest goals (many planted lots were still developed), and did little if anything to prevent the overall gentrification of the area; indeed, the surviving gardens today, now largely preserved by the city, are undoubtedly a boon to neighboring property values.

${ }^{8}$ Changing attitudes toward graffiti provide an interesting parallel. Although studies continue to suggest that graffiti can have a significant negative impact on property values (e.g., Gibbons 2004), in other areas the aesthetics and culture of graffiti and street art have clearly become associated with hip "grit as glamour" gentrification (Lloyd 2006) and have a substantial degree of corporate cooptation to show for it (Alvelos 2004). Edwards (2009) has suggested that the aesthetic qualities and potential popular appeal of some street art demand a reappraisal of the applicability of criminal damage and vandalism laws to these acts in certain contexts.

\section{REFERENCES}

Alvelos, Heitor. 2004. "The Desert Imagination in the City of Signs: Cultural Implications of Sponsored Transgression and Branded Graffiti." In Cultural Criminology Unleashed, edited by J. Ferrell, K. Hayward, W. Morrison, and M. Presdee. London: Glass House Press.

Bartholome, Lynn, and Philip Snyder. 2004. "Is it Philosophy or Pornography? Graffiti at the Dinosaur Bar-BQue.” Journal of American Culture 27(1):86-98.

Bloom, Brett, and Ava Bromberg, eds. 2004. Belltown Paradise/Making Their Own Plans. Chicago, IL: White Walls.

Bourriaud, Nicolas. 2002 [1998]. Relational Aesthetics, translated by S. Pleasance and F. Woods. Paris: Le presses du reel.

Brenner, Neil, Jamie Peck, and Nik Theodore. 2010. "After Neoliberalization?" Globalizations 7(3):327-45.

Burnham, Scott. 2012. Urban Guide for Alternative Use: The City as Source Material. Available at http://www. altuseguide.com. Accessed 21 June, 2012.

Chalfant, Henry, and James Prigoff. 1987. Spraycan Art. New York and London: Thames and Hudson.

Correal, Anne. 2009. “April Showers Bring Seed-Sewing Volunteers.” The New York Times, New York Ed., 12 April: A27. 


\section{DO-IT-YOURSELF URBAN DESIGN}

Douglas, Gordon C. C. 2011a. "DIY Urban Design, From Guerrilla Gardening to Yarn Bombing," GOOD, 12 April, 2011. Available at: http://www.good.is/post/diy-urban-design-from-guerrilla-gardening-toyarn-bombing/. Accessed 21 June, 2012.

—. 2011b. "Do-it-Yourself Urban Design: 'Improving' the City Through Unauthorized, Creative Contributions." Paper Presented in the Regular Session on Popular Culture at the American Sociological Association Annual Conference, Las Vegas, 21 August.

2012. "Do it Yourself Urban Design in the Help Yourself City." In Spontaneous Interventions: Design Actions for the Common Good, edited by C. L. Ho and G. Douglas. Washington, DC: Architect/Hanley Wood.

Edwards, Ian. 2009. "Banksy's Graffiti: A Not-so-simple Case of Criminal Damage?” The Journal of Criminal Law 73:345-61.

Fairbanks, Robert P. II, and Richard Lloyd. 2011. "Critical Ethnography and the Neoliberal City: The US Example." Ethnography 12(1):3-11.

Fairey, Shepard. 1990. "Manifesto." Obey website. Available at http://obeygiant.com/about. Accessed 14 Aug. 2011.

Farr, Jo-Ann H., and Carol Gordon. 1975. "A Partial Replication of Kinsey's Graffiti Study.” Journal of Sex Research $11(2): 158-63$.

Ferrell, Jeff. 1995. "Urban Graffiti." Youth and Society 27(1):73-92.

- 2001. Tearing Down the Streets: Adventures in Urban Anarchy. New York: Palgrave.

Finn, Donovan. Forthcoming. "DIY Urban Design: Opportunities and Challenges for Planners." The Journal of Urbanism.

Fishman, Robert, ed. 2000. The American Planning Tradition. Washington, DC: Woodrow Wilson Center.

Florida, Richard. 2002. The Rise of the Creative Class: And How It's Transforming Work, Leisure, Community, and Everyday Life. New York, NY: Basic Books.

Ganz, Nicholas. 2004. Graffiti World: Street Art from Five Continents. New York, NY: Harry N. Abrams.

Gibbons, Steve. 2004. "The Costs of Urban Property Crime." The Economic Journal 114:441-63.

Harvey, David. 2006. Spaces of Global Capitalism: A Theory of Uneven Geographical Development. London and New York: Verso.

Ho, Cathy Lang, and Gordon Douglas (eds). 2012. Spontaneous Interventions: Design Actions for the Common Good. Washington, DC: Architect/Hanley Wood.

Hou, Jeffrey (ed). 2010. Insurgent Public Space: Guerrilla Urbanism and the Remaking of Contemporary Cities. New York, NY: Routledge.

Iveson, Kurt. 2012. "Cities Within the City: Do-It-Yourself Urbanism and the Right to the City." Paper presented at the Center for Place Culture and Politics and the Public Space Working Group, CUNY Graduate Center, New York, February 23.

- 2013. "Cities Within the City: Do-It-Yourself Urbanism and the Right to the City." International Journal of Urban and Regional Research 37(3):941-56.

Keizer, Kees, Siegwart Lindenberg, and Linda Steg. 2008. “The Spreading of Disorder.” Science 322(5908): 1681-85.

Keller, Lisa. 2009. Triumph of Order: Democracy and Public Space in New York and London. New York and London: Columbia University Press.

Kidder, Jeffrey. 2011. Urban Flow: Bike Messengers and the City. Ithaca, NY: ILR Press.

- 2012. "Parkour, the Affective Appropriation of Urban Space, and the Real/Virtual Dialectic." City E Community 11(3):229-53.

Kimmelman, Michael. 2010. "D.I.Y. Culture.” The New York Times, New York Ed., 18 April:AR1,19.

Kinsey, Alfred C., Wardell B. Pomoroy, Clyde E. Martin, and Paul H. Gebhard. 1953. Sexual Behavior in the Human Female. Philadelphia: Saunders Co.

Klanten, Robert, Sven Ehmann, and Matthias Hubner (eds). 2010. Urban Interventions: Personal Projects in Public Spaces. Berlin and London: Gestalten.

Kwon, Miwon. 2002. One Place After Another: Site-Specific Art and Locational Identity. Cambridge, MA \& London: MIT Press.

Lacy, Susan (ed). 1995. Mapping the Terrain: New Genre Public Art. Seattle: Bay Press.

Lambert-Beatty, Carrie. 2010. "Fill in the Blank: Culture Jamming and the Advertising of Agency." New Directions for Youth Development 125:99-112.

Lefebvre, Henri. 2008 (1947). Critique of Everyday Life Vol. I: Introduction. 2nd Ed., translated by J. Moore. London and New York: Verso. 


\section{CITY \& COMMUNITY}

2009 (1966). "Theoretical Problems of Autogestion." In State, Space, World: Selected Essays, edited by N. Brenner, and S. Elden, translated by G. Moore, N. Brenner, and S. Elden. Minneapolis and London: University of Minnesota Press.

Leland, John. 2004. Hip: The History. New York: Harper Collins.

Levy, John M. 2011. Contemporary Urban Planning. 9th Ed. Boston, MA: Longman.

Lloyd, Richard. 2006. Neo-Bohemia: Art $\mathcal{E}$ Commerce in the Postindustrial City. New York, NY: Routledge.

Lydon, Mike. 2011. Tactical Urbanism Handbook. Vol. 1. Available at: http://www.scribd.com/khawarzad/d/ 51354266-Tactical-Urbanism-Volume-1. Accessed June 22, 2012. Published online March 23, 2011.

Manco, Tristan. 2004. Street Logos. New York and London: Thames and Hudson.

Moore, Mandy, and Leanne Prain. 2009. Yarn Bombing: The Art of Crochet and Knit Graffiti. Vancouver, BC: Arsenal Pulp Press.

Partizaning. 2012. Partizaning: Participatory Urban Planning. Available at: http://eng.partizaning.org/. Accessed 21 June, 2012.

Phillips, Susan A. 1999. Wallbangin': Graffiti and Gangs in L.A. Chicago, IL: University of Chicago Press.

Pickerill, Jenny, and Paul Chatterton. 2006. "Notes Towards Autonomous Geographies: Creation, Resistance and Self-Management as Survival Tactics." Progress in Human Geography 30(6):730-46.

Rahn, Janice. 2002. Painting Without Permission: Hip-Hop Graffiti Subculture. Westport, CT: Bergin and Garvey.

Reynolds, Richard. 2004. On Guerrilla Gardening: A Handbook for Gardening Without Boundaries. New York, NY: Bloomsbury.

Ryzick, Melena. 2007. "Where the Crafts Babes and D.I.Y. Dudes Are." The New York Times online, 14 June. Available at: http://www.nytimes.com/2007/06/24/fashion/24renegade.html. Accessed 16 August 2012.

Sampson, Robert J., and Steven W. Raudenbush. 1999. "Systematic Social Observation of Public Spaces: A New Look at Disorder in Urban Neighborhoods." American Journal of Sociology 105(3):603-51.

Schmelzkopf, Karen. 1995. "Urban Community Gardens as Contested Space." Geographical Review 85(3):364-81.

Scott, James C. 1985. Weapons of the Weak: Everyday Forms of Peasant Resistance. New Haven, CT, and London: Yale University Press.

Seno, Ethel, Carlo McCormick, Marc Schiller, and Sarah Schiller (eds). 2010. Trespass: A History of Uncomissioned Urban Art. Los Angeles and Köln: Taschen.

Small, Mario Luis. 2009. "How Many Cases Do I Need? On Science and the Logic of Case Selection in Field Research." Ethnography 10(1):5-38.

Smith, Neil. 2008 (1984). Uneven Development. 3rd Ed. Athens, GA: University of Georgia Press.

Snyder, Gregory J. 2009. Graffiti Lives: Beyond the Tag in New York's Urban Underground. New York and London: NYU Press.

St. John, Graham. 2004. "Counter-Tribes, Global Protest, and Carnivals of Reclamation." Peace Review 16(4): $421-28$.

Stern, Steven. 2010. "Brooklyn: The Brand.” The New York Times, New York Ed., 15 Dec.:D5.

Sutcliffe, Anthony. 1981. Towards the Planned City: Germany, Britain, the United States and France 1780-1914. Oxford: Basil Blackwell.

Thompson, Nato, and Gregory Sholette (eds). 2004. The Interventionists: Users' Manual for the Creative Disruption of Everyday Life. Boston and North Adams, MA: MIT Press and MASS MoCA.

Tilly, Charles. 1978. From Mobilization to Revolution. Reading, MA: Addison-Wesley.

Veloz, Jimena. 2011. "WikiCity - How Citizens Improve Their Cities." This Big City website. Available at: http://thisbigcity.net/wikicity-citizens-improve-cities/. Accessed 21 June, 2012.

Visconti, Luca M., John F. Sherry Jr., Stefania Borghini, and Laurel Anderson. 2010. "Street Art, Sweet Art? Reclaiming the 'Public' in Public Space.” Journal of Consumer Research 37(3):511-29.

Vivoni, Francisco. 2009. "Spots of Spatial Desire: Skateparks, Skateplazas, and Urban Politics." Journal of Sport and Social Issues 33(2):130-49.

Von Hassell, Malve. 2002. The Struggle for Eden: Community Gardens in New York City. Santa Barbara, CA: Praeger.

Wilson, James Q., and George Kelling. 1982. "The Police and Neighborhood Safety: Broken Windows." The Atlantic Monthly 127:29-38.

Wilson, Peter L., and Bill Weinberg, eds. 1999. Avant Gardening: Ecological Struggle in the City and the World. Brooklyn, NY: Autonomedia.

Yin, Robert. 2010. Case Study Research: Design and Methods 3rd Ed. Thousand Oaks, CA, London, and New Delhi: Sage.

Zukin, Sharon. 2010. Naked City: The Death and Life of Authentic Urban Places. Oxford and New York: Oxford University Press. 


\section{Diseño Urbano "Hágalo Usted Mismo": La Práctica Social de "Mejora” Informal a través de Alteraciones Desautorizadas (Gordon C. C. Douglas)}

\section{Resumen}

Existen muchas formas por las cuales la gente hace alteraciones ilegales o desautorizadas al espacio urbano. Este estudio identifica y analiza una de estas formas que ha sido ignorada en las ciencias sociales: contribuciones informales que son explícitamente funcionales y de espíritu cívico a las que llamo "diseño urbano hágalo usted mismo" (DIY por sus siglas en inglés). Esta investigación, que empezó como una investigación sobre alteraciones más "tradicionales", muestra casos -desde ciclovías hechas en casa y símbolos callejeros hasta jardines por invasión y propuestas de desarrollo- que ganan visibilidad en varias ciudades y que sin embargo son poco reconocidos por las perspectivas existentes en la literatura urbana. Este artículo examina las teorías existentes y evidencia de entrevistas y otro trabajo de campo en catorce ciudades, a fin de desarrolla la categoría analítica nueva de "diseño urbano hagalo usted mismo." Presento información sobre los creadores de estas intervenciones, en sus motivaciones para "mejorar" la infrastructura urbana donde se percibe al gobierno y a otros actores del desarrollo como poco efectivos, y en la concentración de sus esfuerzos en áreas en gentrificación. Esto genera posibilidades de conflicto y complica sus impactos. Señalo que el Diseño Urbano Hágalo Usted Mismo tiene implicancias de alta trascendencia tanto para comunidades locales como para políticas urbanas más amplias. 